\title{
Determination of methane content and methane released when exploiting longwall at different levels at 13.2 seams, Khe Cham coal mine, Vietnam
}

\author{
Van Thinh Nguyen $^{1 *}$ \\ ${ }^{1}$ Underground Mining Department, Hanoi University of Mining and Geology, Vietnam
}

\begin{abstract}
Khe Cham coal mine is managed by Ha Long Coal Company TKV. Currently, Khe Cham coal mine is exploited from the ground up to 350 and is ranked III for methane. In 2008, a methane explosion at -168 level of the 13.2 coal seam of Khe Cham coal mine occurred, injuring 16 people and killing 8. In order to avoid gas explosions at mines like 2008, it is necessary to have appropriate solutions to eliminate methane accumulation in the pit paths. We have studied to determine the relationship between the level of methane emissions with the methane content in the coal seam and the bazaar's mining output because of the methane content in the coal seam and coal mining output. These are the two factors that greatly affect the release of methane from the longwall. The paper used practical measurement, sampling, and analysis methods to determine the level of methane emissions from longwalls at different extraction levels of the 13.2 coal seam and determine the relationship between the methane drainage and the methane content in the coal seam and the exploitation output of the longwall. This relationship is expressed by the equation $y=a \cdot x^{2}+b \cdot x+c$ (Fig. 2 and Fig. 3). The results will help with planning for mining and have specific solutions for diluting methane in the mine's pit lines
\end{abstract}

\section{Introduction}

Khe cham underground coal mine is located in MongDuong town, CamPha city, Quang Ninh province, Vietnam. The North, it borders on Duong Huy commune; The East, it borders on Quang Loai, Mong Duong commune; + The South, it borders on KheSim, Coc Sau, Deo Nai, Lo Tri; The West, it borders on KheTam coal mine Do not add any page numbers.

Table 1. Geographical coordinates of Khe cham coal mine

\begin{tabular}{|c|c|c|c|c|c|}
\hline \multirow{2}{*}{$N_{0}$} & \multirow{2}{*}{ Name of mine } & \multicolumn{2}{|c|}{ Coordinates } & $\begin{array}{c}\text { Z: Deep level } \\
(\mathrm{m})\end{array}$ & $\begin{array}{c}\text { Acreage } \\
\left(\mathrm{km}^{2}\right)\end{array}$ \\
\cline { 3 - 4 } & \multirow{2}{*}{ Khe cham } & $\mathrm{X}$ & $\mathrm{Y}$ & & \\
\cline { 1 - 1 } & 30203 & 425111 & \multirow{2}{*}{+32 level to } & 5,6 \\
\hline
\end{tabular}

* Corresponding author: nguyenvanthinh.hl@humg.edu.vn or nguyenthinhtkv@gmail.com 


\begin{tabular}{|c|c|c|c|}
\hline 3 & 31000 & 427999 & \multirow{19}{*}{-1000 level } \\
\hline 4 & 30965 & 428928 & \\
\hline 5 & 30295 & 429164 & \\
\hline 6 & 30116 & 429289 & \\
\hline 7 & 29998 & 429244 & \\
\hline 8 & 30000 & 429025 & \\
\hline 9 & 29703 & 428894 & \\
\hline 10 & 29496 & 428669 & \\
\hline 11 & 29270 & 428670 & \\
\hline 12 & 28710 & 428381 & \\
\hline 13 & 28189 & 428657 & \\
\hline 14 & 28405 & 428251 & \\
\hline 15 & 28516 & 427983 & \\
\hline 16 & 28543 & 427598 & \\
\hline 17 & 28669 & 427363 & \\
\hline 18 & 29041 & 427205 & \\
\hline 19 & 29108 & 426928 & \\
\hline 20 & 29565 & 426639 & \\
\hline 21 & 29825 & 425735 & \\
\hline
\end{tabular}

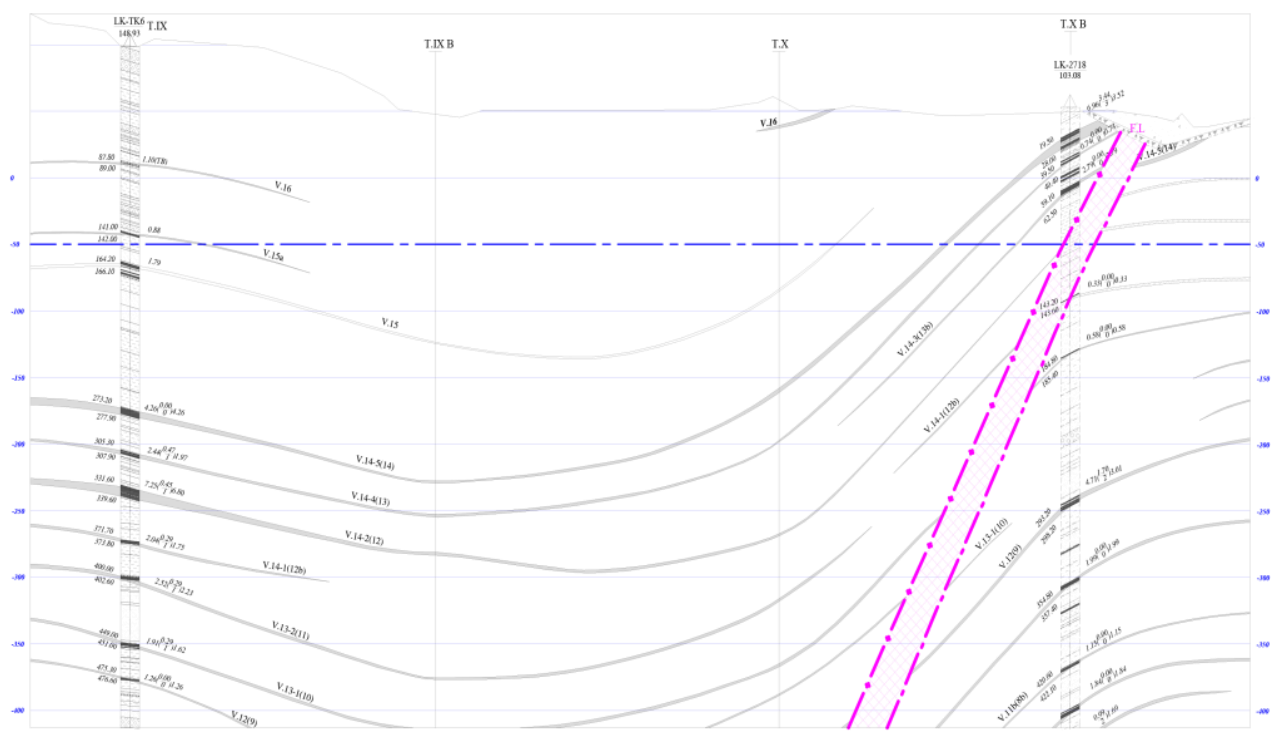

Fig 1. Geological section of Khe Cham coal mine.

Based on the results of determining the $\%$ content of gases, the natural gas content of coal seams in Khe Cham mines, regulations on gas zoning according to the "Guidance on the method of document collection in the search - exploration, and mining, in 2002 of Vietnam Coal Industry Group - Minerals, Khe Cham 1 mines exist three gas zones, as follows:

The Nitrogen-Methane Zone: mainly distributed from the surface up to $+40 \mathrm{~m}$; The methanenitrogen zone: mainly distributed from $+40 \mathrm{~m}$ to $-150 \mathrm{~m}$.

The Methane zone: mainly distributed from -150 and below. In some places like Cao Son, the surface of the floating methane zone is up to $+50 \mathrm{~m}$, in the South of Da mai subdivision at $-50 \mathrm{~m}$ and gradually raised to $+50 \mathrm{~m}$ in the southwestern part of the mine. In the part of Khe Cham, the methane zone is at $-100 \mathrm{~m}$ and sinks up to the Northwest. 


\section{Characteristics of the methane content of Khe Cham coal mine}

Survey measurement data on the gas content of coal seams at different levels, the monthly coal mining output, and the ventilation of the longwall at coal seam 13.2 of Khe Cham coal mine 1 are presented at The following tables: 13.2-2 longwall (-25/-55 level), 13.2-5 longwall (-55/-100 level), 13.2-4 longwall (-100/-125 level), 13.2-6 longwall (-120/-140 level), 13.25 longwall (-140/-168 level), 13.2-6 longwall (-70/-198 level), 13.2-7 longwall (-195/-210 level) [1]

At the coal seam 13.2, there are 7 longwalls with different levels from -25 to -210 during 10 years. We have synthesized the measurement data of methane release at the times of each longwall when the extraction took place.

The methane concentrations in coal seams were sampled at seam 13.2 and brought back to the lab for VARIAN gas chromatography analysis. The methane content results at different levels of coal seams 13.2 are presented in tables $2,4,6,8$, and 10 .

The wind flow in the tunnels of mine (Q) and methane concentrations in the airflow (C) were measured directly at the mine's tunnels.

The absolute methane release (I) is determined by the following formula: [2]

$$
\mathrm{I}=\frac{Q . C}{100}, \mathrm{~m}^{3} / \mathrm{min}
$$

The relative methane release (I) is determined by the following formula: [3]

$$
q=\frac{I . N .24 .60}{A}, \mathrm{~m}^{3} / 24 \mathrm{~h}
$$

Measurement and calculation results are shown in tables 3,5,7,9 and 11

Table 2. Methane content in coal seams at 13.2-2 longwall (-25/-55 level)

\begin{tabular}{|c|c|c|c|}
\hline $\mathrm{N}_{0}$ & Sample survey location & $\begin{array}{c}\text { The depth of the } \\
\text { longwall, } \mathrm{m}\end{array}$ & $\begin{array}{c}\text { Methane content } \\
\left(\mathrm{m}^{3} / \mathrm{Tkc}\right)\end{array}$ \\
\hline 1 & $13.2-2$ longwall (-25/-55 level) & -55 & 1.3 \\
\hline 2 & $13.2-2$ longwall (-25/-55 level) & -30 & 1.15 \\
\hline 3 & $13.2-2$ longwall (-25/-55 level) & -27 & 0.9 \\
\hline 4 & \multicolumn{2}{|c|}{ Average methane content } & 1.1 \\
\hline
\end{tabular}

Table 3. Results of the calculation of the methane release of 13.2-2 longwall (-25/-55 level),2014

\begin{tabular}{|c|l|c|c|c|c|c|c|c|}
\hline $\mathrm{N}_{0}$ & \multicolumn{1}{|c|}{ Parameter } & Jun & July & Aug & Sep & Oct & Nov & Average \\
\hline 1 & $\begin{array}{l}\text { Quantity, } \\
\text { (tons/month) }\end{array}$ & 13000 & 12500 & 14300 & 12300 & 14500 & 14000 & 13433 \\
\hline 2 & $\begin{array}{l}\text { Number of working } \\
\text { days per month, N } \\
\text { (24h) }\end{array}$ & 24 & 27 & 28 & 27 & 28 & 26 & 26.67 \\
\hline 3 & Flow Q (m/min) & 549 & 742 & 830 & 710 & 828 & 830 & 748.17 \\
\hline 4 & $\begin{array}{l}\text { Methane content in } \\
\text { airflow CH4 C (\%) }\end{array}$ & 0.082 & 0.05 & 0.056 & 0.049 & 0.064 & 0.058 & 0.05 \\
\hline 5 & $\begin{array}{l}\text { Absolute methane } \\
\left.\text { releases I (m }{ }^{3} / \mathrm{min}\right)\end{array}$ & 0.4502 & 0.371 & 0.465 & 0.348 & 0.5299 & 0.481 & 0.44 \\
\hline 6 & $\begin{array}{l}\text { Relative methane } \\
\left.\text { release, q (m } \mathrm{m}^{3} / 24 \mathrm{~h}\right)\end{array}$ & 1.20 & 1.15 & 1.31 & 1.10 & 1.47 & 1.29 & 1.25 \\
\hline
\end{tabular}

Table 4. Methane content in coal seams at 13.2-5 longwall (-55/-100 level)

\begin{tabular}{|c|c|c|c|}
\hline$N_{0}$ & Sample survey location & $\begin{array}{c}\text { The depth of the } \\
\text { longwall, } \mathrm{m}\end{array}$ & $\begin{array}{c}\text { Methane content } \\
\left(\mathrm{m}^{3} / \mathrm{Tkc}\right)\end{array}$ \\
\hline 1 & $13.2-5$ longwall (-55/-100 level) & -95 & 2.35 \\
\hline 2 & $13.2-5$ longwall (-55/-100 level) & -75 & 2.15 \\
\hline
\end{tabular}




\begin{tabular}{|c|c|c|c|}
\hline 3 & $13.2-5$ longwall (-55/-100 level) & -73 & 1.6 \\
\hline 4 & $13.2-5$ longwall (-55/-100 level) & -58 & 1.32 \\
\hline 5 & \multicolumn{2}{|c|}{ Average methane content } & 1.82 \\
\hline
\end{tabular}

Table 5. Results of the calculation of the methane release of 13.2-5 longwall (-55/-100 level),2015

\begin{tabular}{|c|c|c|c|c|c|c|c|c|}
\hline $\mathrm{N}_{0}$ & Parameter & Jun & July & Aug & Sep & Oct & Nov & Average \\
\hline 1 & $\begin{array}{|ll|}\begin{array}{l}\text { Quantity, } \\
\text { (tons/month) }\end{array} & \text { A } \\
\end{array}$ & 14534 & 15568 & 13424 & 16394 & 14562 & 12689 & $\begin{array}{c}1452 \\
8 \\
\end{array}$ \\
\hline 2 & $\begin{array}{l}\text { Number of } \\
\text { working days per } \\
\text { month, N (24h) }\end{array}$ & 24 & 28 & 26 & 28 & 27 & 28 & 26.83 \\
\hline 3 & Flow $\mathrm{Q}\left(\mathrm{m}^{3} / \mathrm{min}\right)$ & 420 & 476 & 425 & 530 & 470 & 410 & $\begin{array}{c}455.1 \\
7\end{array}$ \\
\hline 4 & $\begin{array}{l}\text { Methane content } \\
\text { in airflow } \mathrm{CH}_{4} \mathrm{C} \\
\text { (\%) }\end{array}$ & 0.35 & 0.33 & 0.28 & 0.32 & 0.28 & 0.23 & 0.31 \\
\hline 5 & \begin{tabular}{|l} 
Absolute methane \\
releases \\
$\left(\mathrm{m}^{3} / \mathrm{min}\right)$
\end{tabular} & 1.47 & 1.5708 & 1.19 & 1.696 & 1.316 & 0.943 & 1.36 \\
\hline 6 & $\begin{array}{l}\text { Relative methane } \\
\text { release, } \mathrm{q}\left(\mathrm{m}^{3} / 24 \mathrm{~h}\right)\end{array}$ & 3.50 & 4.07 & 3.32 & 4.17 & 3.51 & 3.00 & 3.59 \\
\hline
\end{tabular}

Table 6. Methane content in coal seams at 13.2-4 longwall (-100/-125 level)

\begin{tabular}{|c|c|c|c|}
\hline $\mathrm{N}_{0}$ & \multicolumn{1}{|c|}{ Sample survey location } & $\begin{array}{c}\text { The depth of the } \\
\text { longwall, } \mathrm{m}\end{array}$ & $\begin{array}{c}\text { Methane content } \\
\left(\mathrm{m}^{3} / \mathrm{Tkc}\right)\end{array}$ \\
\hline 1 & $13.2-4$ longwall (-100/-125 level) & -125 & 2.6 \\
\hline 2 & $13.2-4$ longwall (-100/-125 level) & -110 & 2.5 \\
\hline 3 & $13.2-4$ longwall (-100/-125 level) & -120 & 2.33 \\
\hline 4 & $13.2-4$ longwall (-100/-125 level) & -100 & 2.212 \\
\hline 5 & \multicolumn{2}{|c|}{ Average methane content } & 2.41 \\
\hline
\end{tabular}

Table 7. Results of the calculation of the methane release of 13.2-4 longwall (-100/-125 level),2016

\begin{tabular}{|c|c|c|c|c|c|c|c|c|}
\hline $\mathrm{N}_{0}$ & Parameter & Jun & July & Aug & Sep & Oct & Nov & Average \\
\hline 1 & \begin{tabular}{|l}
$\begin{array}{l}\text { Quantity, } \\
\text { (tons/month) }\end{array}$ \\
\end{tabular} & 13475 & 13542 & 16479 & 15820 & 12000 & 17489 & 14800 \\
\hline 2 & $\begin{array}{l}\text { Number of working } \\
\text { days per month, N } \\
(24 h)\end{array}$ & 27 & 25 & 28 & 28 & 22 & 28 & 26.33 \\
\hline 3 & Flow $\mathrm{Q}\left(\mathrm{m}^{3} / \mathrm{min}\right)$ & 648 & 654 & 710 & 788 & 625 & 780 & 700.8 \\
\hline 4 & $\begin{array}{l}\text { Methane content in } \\
\text { airflow } \mathrm{CH}_{4} \mathrm{C}(\%)\end{array}$ & 0.25 & 0.27 & 0.32 & 0.24 & 0.26 & 0.32 & 0.25 \\
\hline 5 & $\begin{array}{l}\text { Absolute methane } \\
\text { releases I }\left(\mathrm{m}^{3} / \mathrm{min}\right)\end{array}$ & 1.62 & 1.77 & 2.27 & 1.89 & 1.63 & 2.50 & 1.95 \\
\hline 6 & $\begin{array}{l}\text { Relative methane } \\
\text { release, } \mathrm{q}\left(\mathrm{m}^{3} / 24 \mathrm{~h}\right)\end{array}$ & 4.67 & 4.69 & 5.56 & 4.82 & 4.29 & 5.75 & 4.97 \\
\hline
\end{tabular}

Table 8. Methane content in coal seams at 13.2-6 longwall (-125/-168 level)

\begin{tabular}{|c|c|c|c|}
\hline $\mathrm{N}_{0}$ & Sample survey location & $\begin{array}{c}\text { The depth of the } \\
\text { longwall, } \mathrm{m}\end{array}$ & $\begin{array}{c}\text { Methane content } \\
\left(\mathrm{m}^{3} / \mathrm{Tkc}\right)\end{array}$ \\
\hline 1 & $13.2-6$ longwall (-125/-168 level) & -168 & 3.101 \\
\hline 2 & $13.2-6$ longwall (-125/-168 level) & -162 & 2.91 \\
\hline 3 & $13.2-6$ longwall (-125/-168 level) & -155 & 2.72 \\
\hline
\end{tabular}




\begin{tabular}{|c|c|c|c|}
\hline 4 & $13.2-6$ longwall (-125/-168 level) & -130 & 2.6 \\
\hline 5 & Average methane content & 2.88 \\
\hline
\end{tabular}

Table 9. Results of the calculation of the methane release of 13.2-6 longwall (-125/-168 level),2017

\begin{tabular}{|c|c|c|c|c|c|c|c|c|}
\hline $\mathrm{N}_{0}$ & Parameter & Jun & July & Aug & Sep & Oct & Nov & $\begin{array}{c}\text { Avera } \\
\text { ge }\end{array}$ \\
\hline 1 & $\begin{array}{ll}\begin{array}{l}\text { Quantity, } \\
\text { (tons/month) }\end{array} & \text { A } \\
\end{array}$ & 14733 & 15241 & 15365 & 14986 & 16892 & 14628 & 15307 \\
\hline 2 & $\begin{array}{l}\text { Number of working } \\
\text { days per month, N } \\
(24 \mathrm{~h})\end{array}$ & 27 & 26 & 27 & 26 & 28 & 26 & 26.67 \\
\hline 3 & Flow Q $\left(\mathrm{m}^{3} / \mathrm{min}\right)$ & 821 & 798 & 808 & 812 & 78 & 780 & 800.5 \\
\hline 4 & $\begin{array}{l}\text { Methane content in } \\
\text { airflow } \mathrm{CH}_{4} \mathrm{C}(\%)\end{array}$ & 0.24 & 0.27 & 0.26 & 0.24 & 0.32 & 0.26 & 0.28 \\
\hline 5 & $\begin{array}{l}\text { Absolute methane } \\
\text { releases I }\left(\mathrm{m}^{3} / \mathrm{min}\right)\end{array}$ & 1.970 & 2.154 & 2.101 & 1.948 & 2.508 & 2.028 & 2.12 \\
\hline 6 & $\begin{array}{l}\text { Relative methane } \\
\text { release, } \mathrm{q}\left(\mathrm{m}^{3} / 24 \mathrm{~h}\right)\end{array}$ & 5.20 & 5.29 & 5.32 & 4.87 & 5.99 & 5.19 & 5.31 \\
\hline
\end{tabular}

Table 10. Methane content in coal seams at 13.2-6.1 longwall (-170/-198 level)

\begin{tabular}{|c|c|c|c|}
\hline $\mathrm{N}_{0}$ & Sample survey location & $\begin{array}{c}\text { The depth of the } \\
\text { longwall, } \mathrm{m}\end{array}$ & $\begin{array}{c}\text { Methane content } \\
\left(\mathrm{m}^{3} / \mathrm{Tkc}\right)\end{array}$ \\
\hline 1 & $13.2-6.1$ longwall (-170/-198 level) & -195 & 4.148 \\
\hline 2 & $13.2-6.1$ longwall (-170/-198 level) & -180 & 3.807 \\
\hline 3 & $13.2-6.1$ longwall (-170/-198 level) & -175 & 3.607 \\
\hline 4 & $13.2-6.1$ longwall (-170/-198 level) & -170 & 3.421 \\
\hline 5 & \multicolumn{2}{|c|}{ Average methane content } & 3.78 \\
\hline
\end{tabular}

Table 11. Results of the calculation of the methane release of longwall (-170/-198 level), 2018

\begin{tabular}{|c|l|c|c|c|c|c|c|c|}
\hline $\mathrm{N}_{0}$ & \multicolumn{1}{|c|}{ Parameter } & Jun & July & Aug & Sep & Oct & Nov & $\begin{array}{c}\text { Avera } \\
\text { ge }\end{array}$ \\
\hline 1 & $\begin{array}{l}\text { Quantity, A } \\
\text { tons/month) }\end{array}$ & 17322 & 18638 & 18275 & 18841 & 18436 & 17441 & 18158 \\
\hline 2 & $\begin{array}{l}\text { Number of working } \\
\text { days per month, N } \\
\text { (24h) }\end{array}$ & 27 & 28 & 27 & 28 & 28 & 26 & 27.33 \\
\hline 3 & Flow Q (m $\left.{ }^{3} / \mathrm{min}\right)$ & 842 & 1044 & 986 & 1021 & 1112 & 876 & 980.1 \\
\hline 4 & $\begin{array}{l}\text { Methane content in } \\
\text { airflow } \mathrm{CH}_{4} \mathrm{C}(\%)\end{array}$ & 0.24 & 0.28 & 0.29 & 0.32 & 0.27 & 0.26 & 0.25 \\
\hline 5 & $\begin{array}{l}\text { Absolute methane } \\
\text { releases I (mmin) }\end{array}$ & 2.021 & 2.923 & 2.859 & 3.267 & $\begin{array}{c}3.002 \\
4\end{array}$ & 2.277 & 2.73 \\
\hline 6 & $\begin{array}{l}\text { Relative methane } \\
\left.\text { release, q (m }{ }^{3} / 24 \mathrm{~h}\right)\end{array}$ & 4.54 & 6.32 & 6.08 & 6.99 & 6.57 & 4.89 & 5.90 \\
\hline
\end{tabular}

To determine the relationship between the emitted methane concentration and the methane content in the coal seam and the mining output of the 13.2 coal seam at Khe Cham 1 coal mine, we used Microsoft Excel software to build the chart variation in production and methane emissions according to each mining month of each long wall. [4]

From there, determine the regression function showing the variation in yield and methane release, and at the same time build a chart showing the relationship between methane content and methane emissions [5] 


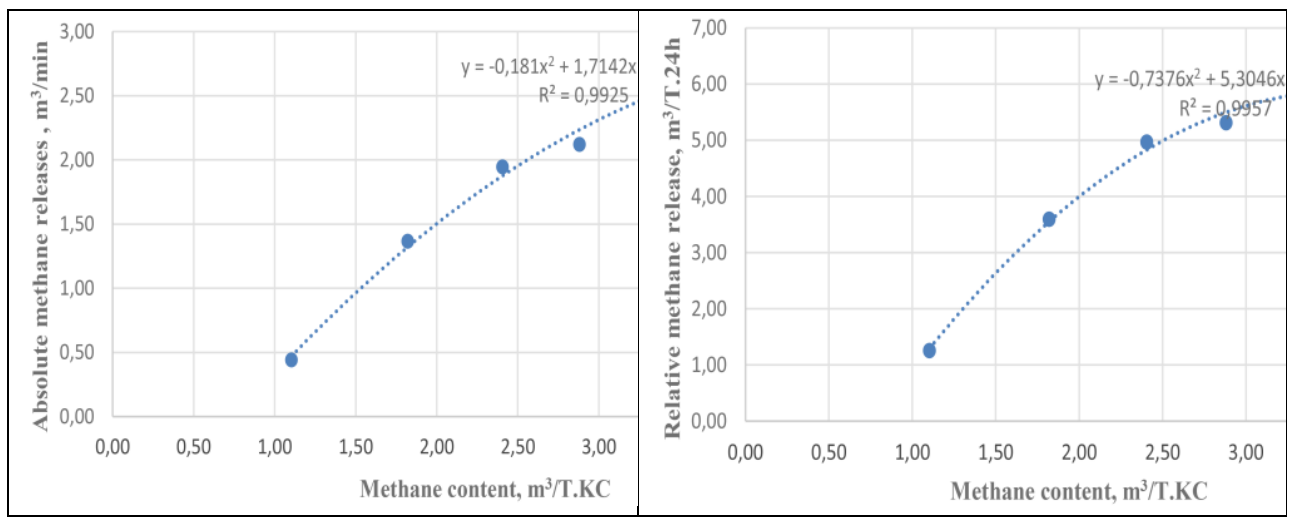

Fig 2. the relationship between the methane content and the methane release of longwalls in the 13.2 coal seam

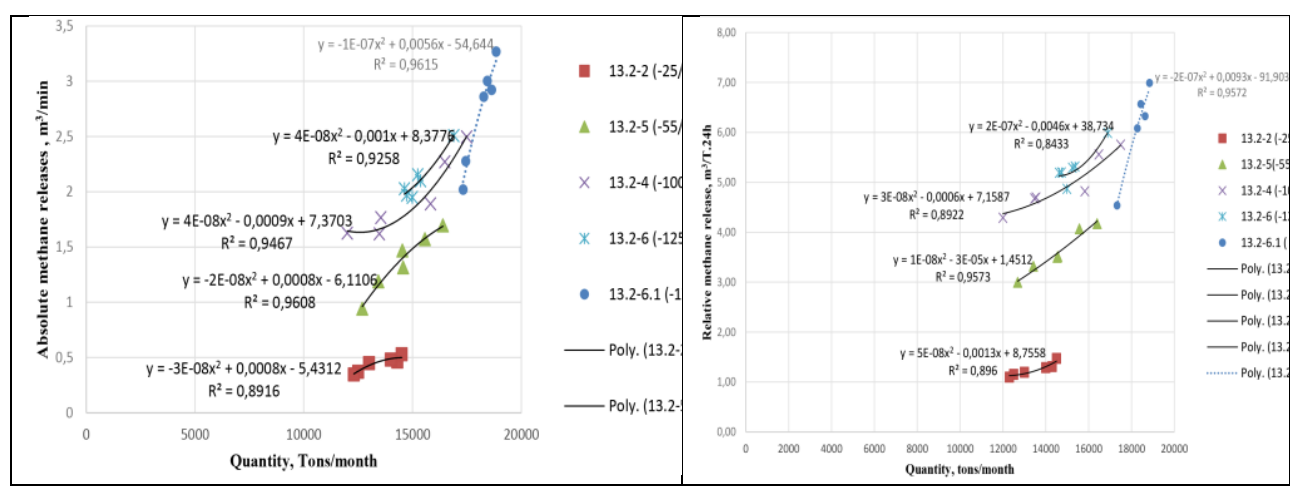

Fig 3. the relationship between the quantity and the methane release in the longwalls of the 13.2 coal seam

\section{Conclusion}

Analyzing the effect of the methane content of coal seams on the absolute and relative methane gas release, we can confirm that:

1. The absolute methane clearance increases and decreases in accordance with the tendency of the increase and decrease of the storage capacity methane gas in coal seams.

2. Relative methane emissions also increased or decreased proportionally with an increase or decrease in coal seams' methane concentrations.

In the same long wall, when production increases, absolute methane release increases, and when production decreases, absolute methane release decreases. Thus, the absolute methane emissions increase and decrease in the same direction as the longwalls' output.

In the same long wall, when the output of a longwall is increased, the relative methane release decreases, and when the output of the longwall is reduced, the relative methane release increases. Thus, the relative increase in methane emissions in the opposite direction of the increase and decrease of longwalls output. 


\section{Acknowledgments}

The author would like to express his sincere thanks to the Vietnam Coal-Mineral Industry Group for providing monitoring data on methane concentrations in the mine lines of the Khe Cham coal mine.

\section{Reference}

1. V. T. Nguyen, Study the methane emission regime when exploiting deep underground coal mines in Quang Ninh, Technical doctoral thesis, Hanoi University of mining and geology, (2019)

2. X. H. Tran, V. S. Nguyen, C. K. Nguyen, V. T. Nguyen, and Q. V. Phan, Curriculum of industrial hygiene and safety in underground mining, (Science and Technics Publishing House, Vietnam, 2012)

3. X. H. Tran, V. C. Dang, C. K. Nguyen, and V. T. Nguyen, The mine ventilation curriculum, (Science and Technics Publishing House, Vietnam, 2014)

4. M. Du, Q. Zhu, X. Wang, P. Li, B. Yang, H. Chen, M. Wang, and Xiaolu (2018).

Estimates and Predictions of Methane Emissions from Wastewater in China from 2000 to 2020, Earth's futur. 6, 252 (2018)

5. C. R. Clarkson, Production data analysis of unconventional gas wells: Review of theory and best practices, Int. J. Coal Geol. 109, 101 (2013) https://dx.doi.org/10.1016/j.coal.2013.01.002

6. S. Saurabh, S. Harpalani, and V.K. Singh, Implications of stress re-distribution and rock failure with continued gas depletion in coalbed methane reservoirs, Int. J. Coal Geol. 162, 183 (2016) https://dx.doi.org/10.1016/j.coal.2016.06.006

7. V. T. Nguyen, W. Mijał, and V. C. Dang, Methane estimation in DuongHuy coal mine, $4^{\text {th }}$ International conference scientific-research cooperation between Vietnam and Poland, (E3S Web of Conferences, 2018), p.01005 https://doi.org/10.1051/e3sconf/20183501005 